保健物理，29，207～211（1994）

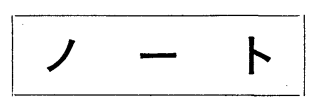

\title{
解析ツリーの手法を用いた大学の放射線管理業務における マンパワーの現状分析と最適な配置の試み
}

\author{
別所 遊子*1, 草間 朋子*2
}

\author{
(1994 年 1 月 14 日受理) \\ (1994 年 3 月 24 日再受理) \\ Analysis of the Optimum Arrangement of Man-power in the Radiological \\ Safety Section of a University Using Analytical Tree Method
}

Yuko BESSHo*1 and Tomoko KUSAMA*2

KEY WORDS : radiological protection, efficiency, optimize, man-power, rearrangement, analytical tree method, time study, priority, self estimation

\section{1. はじめに}

大学を含め放射線事業所に拈ける放射線管理業務は, 日常的な業務を遂行することに追われる傾向にあり，業 務全体が効率的に行われているか否かを評価する機会は 少ない。放射線事業所に拈ける放射線の使用の状況, 施 設設備の状況, および, 放射線管理要員の構成等は時間 の経過とともに変化するので, 放射線管理業務を定期的 に見直し, 効果的かつ効率的に放射線管理業務が行われ ているかどらかを自己評価することが必要である。

操業段階に括ける放射線防護の最適化の解析を定性的 に行う手法の一つとして, 解析ツリーを利用して要素を 系統的に分析する方法が, IAEA の Safety Series ${ }^{1)} て ゙$ 提案されている。放射線防護のための解析ツリーとは,

「あるべき効果的な放射線防護」を頂点に置き, それを

*1 東京大学医学部放射線研究施設; 東京都文京区本郷 7-3-1 (T113)

Radioisotope Research Institute, Faculty of Medicine, The University of Tokyo; 7-3-1, Hongo,

Bunkyo-ku, Tokyo 113, Japan.

*2 東京大学医学部放射線健康管理学; 東京都文京区本郷 7-3-1 ( $\mathbf{\top} 113$ )

Department of Radiological Health, Faculty of Medicine, The University of Tokyo; 7-3-1, Hongo, Bunkyo-ku, Tokyo 113, Japan.
達成するために必要な要素を分析, 列挙し, さらにそれ を下位の細かい要素に分岐させた樹状図で, 要素間の相 互の関連性や妥当性を体系的に評価するために提案され たものである。そこで著者らは，実際に放射線管理を担 当している大学（研究・教育機関）を対象として, 放射 線管理業務の効率化，とくに放射線管理業務に括ける限 定されたマンパワーを最適に配分するために，解析ツリ 一の手法を適用して放射線管理業務の現状分析を行い, その分析結果にもとづき, 放射線管理業務の優先度（重 要度）を考慮して，マンパワーの適切な再配置を含む放 射線管理業務の改善策を作成した。

\section{2. 放射線管理業務の現状分析の方法}

\section{1 調査の方法}

マンパワーの最適配置を検討するために，まず放射線 管理要員が実際に業務に係わっている時間の分析を行っ た。業務ごとの作業時間の現状を把握するために，時間 調查用紙を作成し，年間を通じて比較的定常的な放射線 管理業務が行われる $1 \sim 3$ 月の時期を選び調查した。調 査期間中, 各室員は毎日自己の業務内容を 10 分単位で 記録した。

\section{2 解析を行った事業所の特徵}

解析の対象とした事業所は, 主として医学生物学実験 
Table 1 調査対象とした大学事業所の概要

\begin{tabular}{|c|c|c|c|c|c|c|c|}
\hline 項目/区域 & \multicolumn{2}{|c|}{ 管理区域 1} & \multicolumn{2}{|c|}{ 管理区域 2} & 管理区域 3 & \multicolumn{2}{|c|}{ 計 } \\
\hline 面 積 $\left(\mathrm{m}^{2}\right)$ & \multicolumn{2}{|c|}{550} & \multicolumn{2}{|c|}{375} & 290 & \multicolumn{2}{|c|}{1,215} \\
\hline 利用申請者数（人） & \multicolumn{2}{|c|}{97} & \multicolumn{2}{|c|}{97} & 17 & \multicolumn{2}{|c|}{211} \\
\hline 延利用者（人・日） & \multicolumn{2}{|c|}{1,051} & \multicolumn{2}{|c|}{918} & 141 & \multicolumn{2}{|c|}{2,110} \\
\hline RI 入庫件数（件） & \multicolumn{2}{|c|}{94} & \multicolumn{2}{|c|}{71} & 6 & \multicolumn{2}{|c|}{171} \\
\hline 使用核種 & ${ }^{3} \mathrm{H}$ & ${ }^{14} \mathrm{C}$ & ${ }^{32} \mathrm{P}$ & ${ }^{35} \mathrm{~S}$ & ${ }^{45} \mathrm{Ca}$ & ${ }^{51} \mathrm{Cr}$ & $125 \mathrm{I}$ \\
\hline 使用数量（MBq） & 893 & 41 & 3533 & 494 & 2 & 48 & 26 \\
\hline
\end{tabular}

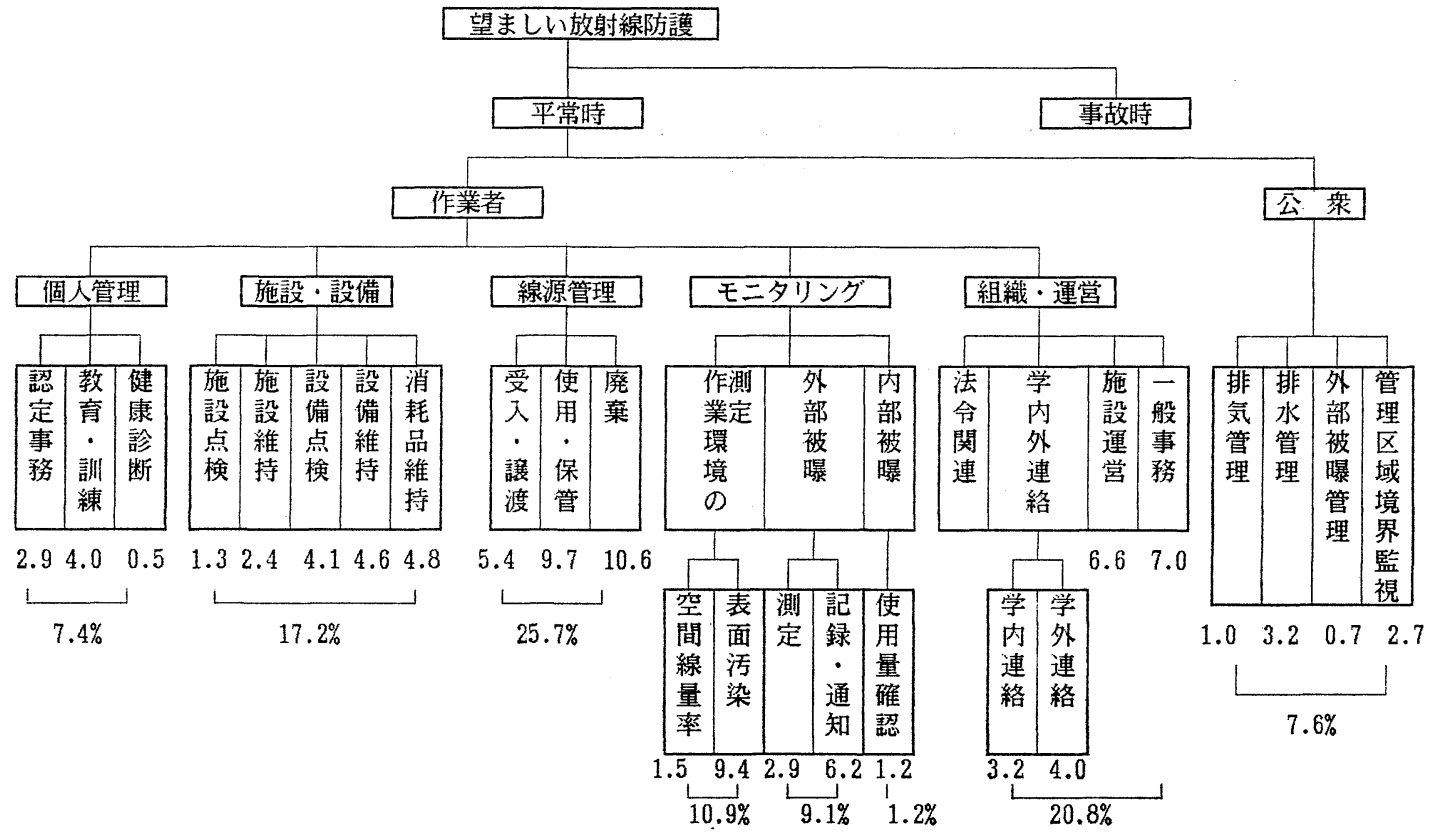

Fig. 1 放射線管理業務の解析ツリーと業務時間調査の結果

においてトレーサーあるいは有機化合物の標識の目的 で, 非密封 RI を使用する大学の医学部 (事業所) で, その概要は Table 1 に示すと和りである。RI を使用す る施設 (管理区域) は3 カ所に分散しており, 施設の合 計面積は約 $1,200 \mathrm{~m}^{2}$, 調査期間中の施設の利用者数は 211 人で，延べ利用者数は 2,110 人・日であり，RI の 購入（搬入）件数は 171 件で, 核種は Table 1 に示すと おりであった。

同事業所に我惊る放射線管理要員は, 常勤職員 1 名, および 5 名の非常勤の要員で構成されており，5名の非 常勤室員の所定の勤務時間数は合計週 70 時間である。 調査期間中に 6 名の放射線管理室員が実際に放射線管理 業務に従事した合計時間数は，延べ 966 時間であった。

\section{3 解析ツリーの作成}

検討対象とした事業所に括ける放射線管理業務のマン パワーの分析を行うために，放射線防護の解析ツリーを つぎの手順で作成した。望ましい放射線防護を達成する ための第一段階の要素として, Fig. 1 に示すように,

「平常時の防護」と「事故時の防護」とに分類し，今回 の検討では平常時の防護に関する放射線管理業務の改善 について考察することにした。平常時の防護を，「作業 者の防護」と「公衆の防護」の 2 つの要素に分類した。 作業者の防護をさらに, 11作業者の個人管理（被曝管理 を除く), (2)施設・設備の維持・管理, (3)線源管理, (4) ニタリング, (5)組織・運営, の5つの下位の要素に分類 し，樹状図を作成した。各要素はそれぞれ，Fig. 1 に示 
解析ツリーの手法を用いた大学の放射線管理業務に括けるマンパワーの現状分析と最適な配置の試み 209

すさらに下位の要素に細分した。

\section{3. 放射線管理業務の時間調查の結果}

上記 2.1 の時間調査用紙を用いて調査した実際の業務 時間を, 解析ツリーの要素の区分に従って分類, 集計 し，各要素に費やした延べ時間数の合計延べ業務時間数 に対する割合を計算し，図中に示した。

\section{(1) 放射線作業者の個人管理}

「放射線作業者の個人管理に関する要素」は，合計作 業時間数の $7.4 \%$ を占めていた。この要素の内訳を調べ た結果は, 毎月 1 回行う新規の放射線作業者に対する教 育・訓練の実施が $4.0 \%$, 新規放射線作業者の認定・解 除の事務作業が $2.9 \%$ ，健康診断の確認関する作業 が， $0.5 \%$ であった。この期間内に，新たに認定および 解除をした放射線作業者数は 25 人であった。

(2) 施設・設備の維持・管理

施設・設備の維持に関する業務は，全体の業務時間数 の $17.2 \%$ を占めていた。さらに 5 つの下位の要素に分 類した結果, 設備の維持が $4.6 \%$, 設備の点検が $4.1 \%$, 消耗品の維持が $4.8 \%$, 施設の点検維持が $3.7 \%$ を占め ていた。調查期間中に，人事院規則に規定された X線装 置特よび電子湿微鏡の定期の漏洩検查（毎年 1 回）が行 われたため，本調查結果にはそれに関連した作業時間数 も含まれている。また，放射線管理設備以外の共同利用 実験機器類, 抢よび一般設備 (電灯等) の点検と維持の 業務時間もこの項に含まれている。

\section{（3）線源管理}

線源管理関する業務は, Fig. 1 亿示すとおり，(1)RI の受入れ・譲渡, (2)RI の使用・保管数量の確認, (3) 廃 棄物の処理に関する業務に分類した。これらを合計する と業務時間の $25.7 \%$ を占めて拈り，5つの分類項目の 中ではもっとも多くの割合を占めていることが，改めて 確認された。項目別に見ると，(1)の RI の受入れ・譲渡 の許可，打よび記録の作成が $5.4 \%$ ，(2)の RI の保管・ 使用数量の集計および記録は $9.7 \%$ であった。(2)の集計 ・記録は，利用者が保管拉よび使用のつぞ記載する保 管・使用記録から，パソコンの集計用プログラムを利用 して管理室員が入力・集計して抒り, 集計結果は RI の 在庫管理, 使用数量, 貯蔵量の許可数量との照合, 内部 被瀑線量の評価の目的で使用している。(3)の廃棄に関す る業務は $10.6 \%$ であった。廃棄に関する業務は，作業 者が実験室から廃棄物保管室へ放射性廃棄物を移動する 際の立会い，廃棄の記録の集計，および日本アイソトー プ協会による廃棄物の集荷の際の集荷記録票の作成, 拧 よび集荷の立会いの業務が含まれている。

(4) モニタリング
モニタリングに関する業務は，(1)場所の放射線の測定 - 評価, (2)作業者の外部被曝線量の測定, および, (3)内 部被曝線量の測定・評価の 3 つの下位の要素, 呿よび 5 つのさらに下位の要素に分類し, 合計 $21.2 \%$ を占めて いた。「場所の測定」は，表面污染測定・評価とその記 録，基準値を超光た場合の除染等の業務が $9.4 \%$ ，空間 線量の測定は $1.5 \%$ であった。

「外部被曝」に関連する業務は, フィルムバッジの測 定・評価記録の作成と，作業者への評価結果の通知が $6.2 \%$ で比較的大きな割合を占めて拉り，この内フィル

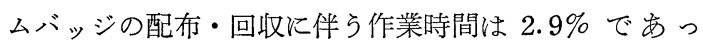
た。「内部被曝線量の評価」は, 作業者の個人ごとの害 測は行わず，使用数量から計算により行っている。その ための放射線管理業務時間数としては $1.2 \%$ に過ぎず, 相対的に小さな割合である。

(5) 組織・運営

組織・運営に関する業務は, Fig. 1 亿示すように, 法 規制関連業務，学内外の連絡・交渉，施設運営に関する 業務, 一般事務業務の 4 要素に分類し, 合計 $20.8 \%$ の 割合を占めていた。この中では, 施設運営に関連する学 部内委員会, 施設利用者との連絡会議, 管理区域への立 入り者の許可事務などを含む「施設運営」が $6.6 \%$, 施 設運営経費に関する事務を含む一般事務作業が $7.0 \%$ で あった。学内外の連絡業務は合計 $7.2 \%$ であった。

(6) 公衆の放射線防護

公衆の放射線防護に関する要素は, Fig. 1 亿示すよう 飞, (1)管理区域境界の監視，(2)放射性同位元素の排気管 理，(3)排水管理，(4)管理区域境界の線量率管理に関する 4 つの下位の要素に分類した。それぞれ全体の業務時間 数に対して，1.0，3.2，0.7，2.7\% を占めており, 合計 $7.6 \%$ であった。

\section{4. 放射線管理業務のマンパワーの配分に関する改善 点}

放射線管理業務の改善, すなわちマンパワーを再配分 するに当たっては, 現状調査の分析結果と, 個々の放射 線管理業務の優先度を考慮して改善策を作成することと した。

\section{1 放射線管理業務の優先度}

放射線管理業務の優先度は, 放射線管理の考方方や経 験をもとに，Table 2 のように考觉た。

(1) 優先度が高い放射線管理業務

(a) 線源の所在抢よび数量の管理

放射線防護に括ける個々の放射線管理業務の優先度 は, 線源一環境一人のネットワーク22 と関連させて考察 することが有用であると思われる。放射線管理は, 線源 
Table 2 放射線管理業務の優先度の分類

\begin{tabular}{clll}
\hline 対象 $\backslash$ 優先度 & \multicolumn{1}{c}{ 高 } & \multicolumn{1}{c}{ 中 } & \multicolumn{1}{c}{ 低 } \\
\hline 放射線作業者 & 線源管理 & 場所の線量管理 & 外部被曝管理 \\
& 表面污染管理 & & 内部被曝管理 \\
& 教育・訓練 & & 健康診断 \\
& 施設維持・管理 & & 一般事務 \\
& 排気・排水管理 & 管理区域境界管理 & 外部被曝管理 \\
\hline
\end{tabular}

に対して行らのがもっとも重要で効果的である。したが って，管理の対象とする施設飞おちける RI の受入れ・譲 渡の状況の確認, RI の所在扝よび在庫量の把握の業務 の優先度は高い。

\section{(b) 表面污染の測定と管理}

非密封 RI を実験に使用する場合には，取扱いの過程 で放射性物質の一部が作業環境や作業者污污染として移 行・拡散する可能性が高い。污染を防止するための取扱 い手順を作業者が守っているかを確認し，污染の拡大を 最小限に抑えるために, 表面污染の測定・評価の業務の 重要度は高い。

\section{(c) 教育・訓練}

調査対象とした事業所は, 非密封 RI を実験研究の目 的で使用して抢り, 使用する核種, 数量, 操作の状況が 多種多様である。作業環境の污染防止, あるいは作業者 の被曝線量の低減関して, 作業者自身が安全に対する 一定の意識をもっていることが必要な条件となる ${ }^{3 \sim 5)}$ したがって, 新規に RI を使用するのに先立って作業者 飞対して行う教育・訓練, 捛よび定期的に繰り返し行わ れる教育・訓練が重要であり，それに関連する放射線管 理業務の優先度も高い。

\section{(d) 施設・設備の維持}

事業所に括ける放射線安全のレベルを維持するために は，施設の設計時の能力を維持していることが前提とな る。能力が低下した場合には速やかに検知できることが 必要である。このために, 施設・設備を維持するための 業務の優先度が高い。

（e）公衆に対する放射線防護

施設外の公衆に対する放射線管理業務は, 施設からの 放射性物質の放出管理と管理区域境界の監視の重要度が 高い。

（2）優先度が低い放射線管理業務

(a) 作業者の被曝線量の管理

本事業所のように, 主として非密封 RI を, 生物化学 実験のトレーサーとして, あるいは生理化学物質の標識
（合成）なぞのために使用する場合には, 通常の作業状況 では，作業者が決められた作業手順を守れば，作業者の 外部被懪線量はきわめて低く, 被懪管理の重要性は低 い。放射線健康診断も同様の理由で重要性は低い。ただ し, 比放射能が高い $\beta$ 線核種を小型の樹脂容器に入れて 手で操作する場合には手指の局所モニタリング6)が，ま た，無機のヨウ素化合物を用いた標識実験の際には内部 被曝モニタリング7が必要とされる。

（b）施設の運営拈よび一般事務作業

施設の運営, 特よび一般事務業務は, 放射線管理室よ りる事業所の施設の運営を担当する組織, あるいは事務 部門が行うのが適当であり, 優先度は低いと考兄られ る。

\section{2 放射線管理業務のマンパワーの再配分}

(1) 時間調査の結果明らかになった現在のマンパワー の配分の問題点

3.1 で述べたと㧍り, 放射線管理業務の時間調査の結 果の解析ツリーによる分析結果と, 放射線管理業務の優 先度を比較検討した結果, 現状のマンパワーの配分に関 して, 次の点が明らかになった。

(1) 線源の所在および数量の管理, 表面污染の測定と 管理, 公衆に対する放射線防護の業務は優先度が高く, とくに前二者は現在の業務時間数も大きな割合を占めて おり,とくに問題はない。

(2) 施設・設備の点検・維持関する現在の業務時間 数は必ずしも少なくないが，これには研究用の放射線測 定器の維持等も含まれているため, 放射線施設・設備の 点検に関する時間数は現在よりも増加する必要がある。

(3) 作業者の外部被曝線量の測定, 施設運営, 一般事 務に関する業務時間数は, 優先度は比較的低いにもかか わらず現在の業務時間数が多いため, 検討し直す必要が 出る。

（2）マンパワーの再配分を行うに当たって考慮すべき 事項

放射線管理業務におけるマンパワーの再配分を検討す 
るに際しては, 放射線管理業務の優先度以外に, 次のよ らな事項も関連する。

a . 新たにマンパワーを増加することが可能である か。

b . 外部サービスや省力化機器の導入でマンパワーの

代替が可能であるか。

本事業所の場合， a ， b の選択肢は経費の増加をとも ならため当面実現が困難なので, 現状のマンパワーの合 計量を維持することを前提に, 最適な再配分案を作成す ることを試みた。

(3) マンパワーの配分の改善策の作成

1) マンパワーの配分を増加する項目

「放射線施設の点検」業務の頻度を増加し, 点検の際 には, 施設・設備の破損箇所等の異常の点検だけではな く, 作業者の施設の使用の状況の巡視を含めることとす る。これは, 施設点検の業務時間数の増加であるが, 作 業者に対して具体的な作業状況に即した助言をすること ができるため, 現場における教育・訓練 (on-the-job training : OJT) の時間数の実質的な増加の意味も持っ ている。

2）マンパワーの配分を減少する項目

(a) 優先頻度の比較的低い作業者の被曝線量の管理, とくに「外部被曝の記録」の業務時間数が大きい。これ を減少させるために，第 1 に，個人被曝線量記録のパソ コンヘの入力方式をパターン化し, 入力作業の効率化を 図る。将来的には，フィルムバッジ測定サービス機関か ら個人被曝線量記録を有料で入手することを検討する。

（b）優先度は低いが，現状では作業時間として比較的 大きい「施設運営」拈よび「一般事務作業」は，将来は 放射線管理室から事業所の事務部門に移行してゆくこと を考慮する。

3) マンパワーの現状の配分を維持する項目

(a)「線源管理」に関する業務時間は, 前述のとおり 現状ではかなり大きな割合を占めている。この業務の優 先度は高く，マンパワーの現状の配分を維持するが，将 来的にはコンピュータを利用した省力化を志向する。

(b)「表面污染管理」は, 前述のと拉り優先度の高い 項目であり, 現状ど扣り毎月作業者が1回，および放射 線管理室が 1 回の合計 2 回測定を行ら。この頻度は, 放 射線管理の経験から得られた現状にもっとも適した測定 頻度と考えられるので変更する必要はなく, 「公衆に対 する放射線防護」とともに，現在の業務時間配分を維持 する。

(4) マンパワーの再配分

（1)に述べた業務時間数の増加は，(2)に述べた時間数の
減少で補ら。

\section{5. 結 論}

事業所に打ける放射線管理業務に関して, 監督庁ある いは監督機関による立入検査の際に改善事項の指摘・指 導を受けることはあるが，日常的に専門的な第 3 者機関 の助言や評価を受ける機会は少ない。解析ツリーの手法 を用いて事務所に和ける現行の放射線管理業務を自己分 析した結果, 必要な業務の見落としを発見し、また現行 の管理要員のマンパワーの配置を再評価し, 効率化を図 るべき業務を発見することなどに役立てらることを，今 回の検討で改めて確認した。

コンピュータなどの利用による放射線管理業務の機械 化の程度や, 放射線管理要員の知識・技術・経験などに よって, 放射線管理業務の優先度をどのように考光, 限 定されたマンパワーをいかに配分するかは，事業所によ って異なり，個々の事業所で考慮すべき事項である。本 研究で示したよらに, 事業所に拉ける放射線管理業務を 全体として評価した場合に, 比較的優先度の低い業務に 多くのマンパワーが配置されている現状を客観的に明ら かにすることができれば，マンパワーの適切な再配分を 検討する際にとくに役立つと思われる。

本研究で用いた，業務時間調查と解析ツリーを組み合 わせた方法は，放射線管理業務の経験を活用して比較的 簡便に行らことができ，乙かも有用な方法であるので， 今後もこの方法を用いて定期的に見直しを行いたいと考 えている。

\section{参考文 献}

1) IAEA ; Safety Series No. 101, 102 (1990).

2) ICRP; 1990 recommendations of the international commission on radiological protection, ICRP Publication 60 (1991).

3）別所遊子, 甲斐倫明, 草間朋子, 吉澤康雄; 大学 に打ける放射線取扱者に対する教育訓練の進め方 について一放射線取扱者を対象としたアンケート 調査の結果に基ついて一, Isotope News, 6, 1823 (1988).

4) 別所遊子; 大学に和ける放射線安全教育・訓練の 進め方, 保健物理, 25, 180-184 (1990).

5）別所遊子，杉本はるみ，草間朋子；大学に特ける 放射線作業者の安全に関する意識調查と調查結果 の放射線管理実務への活用, Isotope News, 5, 1317 (1994).

6) 別所遊子, 福井 徹, 中川健朗, 草間朋子, 吉澤 康雄; ${ }^{2} \mathrm{P}$ 取扱作業者の手指拉よび眼 (水晶体) の放射線被曝管理に関する考察, 保健物理, 22 , 53-57 (1987).

7）小西恵美子, 江口星雄, 吉澤康雄; ${ }^{125}$ I 取扱者の 体内污染について一大学に护経験から一, 保 健物理, 22, 173-177 (1987). 